\title{
THE EFFECT OF GENDER, AGE AND ACADEMIC RANK ON WORK-LIFE BALANCE
}

\author{
Miha Marič \\ Faculty of Organizational Sciences in Kranj, University of Maribor, Slovenia \\ Jasmina Žnidaršič \\ Faculty of Organizational Sciences in Kranj, University of Maribor, Slovenia
}

\begin{abstract}
Work-life balance has been a topic of various researches where researches have been mostly concerned with the influence of organizational practices and policies on work-family balance. On the other side the relation between demographics and work-life balance, particularly in academics sphere, has not been well investigated. Therefore we test in our research how gender, age and the academic rank affect worklife balance among higher education lecturers. Participants in this study were higher education lecturers from Austria, Croatia, Czech Republic, Germany, Serbia and Slovenia. The results of our research show that with a higher academic rank the worklife balance among higher education lecturers' increases. Results show no difference in work-life balance among higher education lecturers based on gender. Potential curvilinearity between age and work-life balance among higher education lecturers was not confirmed due to the lack of statistical significance. The results of this study give better insights into the basic demographics' effect on work-life balance, particularly among higher education lecturers. Results of this study can be used both for further research and in practice.
\end{abstract}

Key words: work-life balance, higher education lecturers, HRM.

JEL classification: 01, 015

\section{UTICAJ POLA, STAROSTI I AKADEMSKOG POLOŽAJA NA ODRŽAVANJE RAVNOTEŽE IZMEĐU POSLOVNOG I PRIVATNOG ŽIVOTA}

Sažetak: Ravnoteža između poslovnog $i$ privatnog života je bila tema različitih istraživanja, u kojima su se istraživači uglavnom bavili uticajem organizacionih praksi $i$

*miha.maric@um.si 


\section{2 | THE EFFECT OF GENDER, AGE AND ACADEMICA RANK ON WORK-LIFE BALANCE}

politika na ravnotežu između posla i porodice. Sa druge strane, odnos demografskih faktora $i$ ravnoteže između poslovnog i privatnog života, posebno u akademskoj sferi, nije dovoljno dobro istražen. Prema tome, u ovom istraživanju autori testiraju kako pol, starost $i$ akademski položaj utiču na ravnotežu između poslovnog $i$ privatnog života predavača $u$ visokom obrazovanju. Učesnici u istraživanju bili su predavači u oblasti visokog obrazovanja iz Austrije, Hrvatske, Češke, Nemačke, Srbije i Slovenije. Rezultati istraživanja ukazuju na to da viši akademski položaj utiče na povećanje ravnoteže između poslovnog i privatnog života predavača u visokom obrazovanju. Rezultati ne ukazuju na postojanje razlike u ravnoteži između poslovnog i privatnog života s obzirom na pol ispitanika. Potencijalna linearna povezanost između starosti i ravnoteže između poslovnog i privatnog života predavača u oblasti visokog obrazovanja nije potvrđena jer se nije došlo do statistički značajnih rezultata. Rezultati ove empirijske studije pružaju bolji uvid u osnovne uticaje demografskih faktora na ravnotežu između poslovnog $i$ privatnog života, posebno među predavačima u oblasti visokog obrazovanja. Rezultati se mogu koristiti za dalja praktična istraživanja.

Ključne reči: ravnoteža između poslovnog $i$ privatnog života, predavači u oblasti visokog obrazovanja, upravljanje ljudskim resursima

\section{INTRODUCTION}

Nowadays, due to a fast pace of life, work-life balance is not always an easy task. Balancing work and family, or balancing the requirements and obligations of working and family life, is therefore an important topic of general conversations between people as well as numerous scientific research. Worklife balance related problems disturb every person, unrelatedly of their level of gender, race, age, education, profession, income, family structure, and status of work (McMillan, Morris and Atchley, 2011). The most common troubles due to the work-life unbalance are being fatigue, underperformance, feeling less qualified and not well at work, dissatisfaction of job and walk-out (Erdamar and Demirel, 2014). Academic work is characterized by the fact that the working day is not precisely defined; therefore education lecturers are often faced with the work-life balance problem.

\section{WORK-LIFE BALANCE}

The problem of the work-life balance is a broad concept and it can be analysed from several aspects: psychological, sociological, gender or aspect of the working environment culture (Sukalova, Ceniga and Janotova, 2015). The psychological aspect focuses on how problems with the work-life balance are connected with stress and work dissatisfaction as well as the psychological health of an individual. The sociological aspect focuses on work-life balance 
from the social state policy point of view, while the gender perspective focuses on the gender differences in the frame of the work-life balance.

The term work-life balance has three components - "work", "life" and "balance" (Suresh and Kodikal, 2017). "Work" is a paid work, or the employment (Guest, 2002), and "life" is all activities outside of work (Suresh and Kodikal, 2017), such as, household activities, friends, family and community (Skinner and Pocock, 2008). Thus, the work-life balance is in a broader sense; the work-life balance could be described as the satisfactory involvement or adaptation between several roles in an individual's life (Bedarkar and Pandita, 2014). Different people will value the work-life balance differently, according to their values and circumstances (Othman, Yusof and Osman, 2009).

There are several factors that influence the individual's work-life balance. They are roughly divided into individual-level factors, organizational-level factors, and country-level factors. Factors at the individual level include the influence of personality traits on the work-life balance (Turliuc and Buliga, 2014), the impact of gender on the work-life balance (Southworth, 2014) as well as parenting and the partner's support in balancing work and personal life (Ferguson, Carlson, Zivnuska and Whitten, 2012).

Another set of factors are the organizational-level factors. For an individual, it is important to perceive the organization as family-friendly, since this significantly influences the reduction of work-family conflict (Lapierre, Spector, Allen, Poelmans, Cooper, O'Driscoll, Sanchez, Brough and Kinnunen, 2008). Organizations can help to reduce work-family conflicts with family-friendly programs that can help an employee to balance work and family or the obligations of working and family life (Boyar, Maertz, Mosley and Carr, 2008). In practice there are several work-life balance policies and practices. The most common are the flexible schedule, the use of overtime, part-time work, "pressed" working week, flexible working hours, work from home, holidays, etc. (Parakandi and Behery, 2016). Employees with access to work-life balance policies and practices often reported better psychological well-being, because the ability to use work-life balance practices enable them sufficient time also for a family and therefore they feel less stress with balancing work and family (Kashyap, Joseph and Deshmukh, 2016). But not only a work-life balance policies and practices are important for employees' work-life balance, numerous studies evidence also an important role of the leader (Greenhaus, Ziegert and Allen, 2012; Maxwell, 2005). On the one hand, the leader contributes to the development of work-life balance policies and practices, and on the other hand plays a key role in the implementation and monitoring of the results of these policies (Maxwell, 2005). 
4 | THE EFFECT OF GENDER, AGE AND ACADEMICA RANK ON WORK-LIFE BALANCE

In addition to the role of the individual and the work organization, researches (Stier, Lewin-Epstein and Braunc, 2012; Roeters, 2011; Trefalt, Drnovsek, Svetina-Nabergoj and Adlesic, 2013) show that the state also significantly influences on work-life balance. With its policies and measures, the state creates more or less favourable conditions for the work-life balance. The main initiatives of the state focus primarily on the field of child care, leave, which provides care for dependent family members, flexible forms of work and equal opportunities for women and men.

Study among teachers (Erdamar and Demirel, 2014) showed that the most common work-family conflict problems are continuing trouble at home confronted at work, a problem that was confronted at work causes tension and stress at home, the physical and mental fatigue at work makes difficult the responsibilities at home, and other. On the other hand, the most common family-work conflict problems are the responsibilities and small works at home causes to make sacrifice from sleeping, the unexpected situations (becoming ill of the child, unplanned guest) at home makes difficult the working life and other.

\section{METHODOLOGY}

\subsection{RESEARCH QUESTIONS}

Based on studied literature and previous research, we propose our three research questions:

RQ1: Is there a difference in work-life balance among higher education lecturers based on gender?

RQ2: Is there a curvilinear relationship between the age and work-life balance among higher education lecturers?

RQ3: Is there a curvilinear relationship between the academic rank and worklife balance among higher education lecturers?

\subsection{PARTICIPANTS}

The full set of questionnaires was completed by a total of 171 online participants, all of which were higher education lecturers, which represent our sample, of whom $68(39.8 \%)$ were men and $103(60.2 \%)$ were women. The average age of respondents was 45.05 years. On the average they had 18.81 years of work experience overall, of which 15.12 were in higher education.

According to the educational level of respondents: 5 (2.9\%) were with B.Sc. or B.A., $35(20.5 \%)$ were with M.Sc. or MBA and $131(76.6 \%)$ had a Ph.D. 
According to their academic rank: $29(17.0 \%)$ were teaching assistants, 16 (9.4\%) were research assistants, 59 (34.5\%) were assistant professors, 36 $(21.1 \%)$ were associate professors and $31(18.1 \%)$ were full professors.

\subsection{INSTRUMENTS}

Descriptive statistics for the variables constructing work-life balance (Brough, Timms, O'Driscoll, Kalliath, Oi-Ling Siu, Sit and Lo, 2014) are presented in Table 1. Higher education lecturers had to indicate for each of the four statements related to work-life balance, on their level of agreement by circling a number ranging from " 1 " - strongly disagree to " 5 " - strongly agree on how strongly they personally agree or disagree with the statement.

Table 1

Means(M) and standard deviations(SD) for the items of work-life balance

\begin{tabular}{lccc}
\hline \multicolumn{1}{c}{ Item } & $\boldsymbol{n}$ & $\mathbf{M}$ & SD \\
\hline $\begin{array}{l}\text { I currently have a good balance between the time I } \\
\text { spend at work and the time I have available for non- } \\
\text { work activities. }\end{array}$ & 171 & 2,97 & 1,348 \\
$\begin{array}{l}\text { I have difficulty balancing my work and non-work } \\
\text { activities. }\end{array}$ & 171 & 3,23 & 1,343 \\
$\begin{array}{l}\text { I feel that the balance between my work demands and } \\
\text { non-work activities is currently about right. }\end{array}$ & 171 & 2,97 & 1,308 \\
$\begin{array}{l}\text { Overall, I believe that my work and non-work life are } \\
\text { balanced. }\end{array}$ & 171 & 3,15 & 1,329 \\
\hline
\end{tabular}

Note. Calculated by the authors.

\subsection{DATA COLLECTION}

We used an online questionnaire, which was sent via e-mail in winter 2018, to obtain data for our analysis. We have used convenience sampling, which is the most common (Etikan, Abubakar Musa and Sunusi Alkassim, 2016), where people from six countries were invited via e-mail to participate in our survey. We have used IBM SPSS Statistics 24 to analyse the data.

\section{RESULTS}

First we wanted to answer $R Q 1$, in which we researched if there is a difference in work-life balance among higher education lecturers based on gender. We found that male higher education lecturers did not have statistically significantly 
6 | THE EFFECT OF GENDER, AGE AND ACADEMICA RANK ON WORK-LIFE BALANCE

higher work-life balance $(3.22 \pm 0.72)$ than female higher education lectures $(2.99 \pm 0.79), \mathrm{t}(169)=1.881, \mathrm{p}=0.062$.

Before testing the curvilinearity of the relationship between age and work-life balance among higher education lecturers, linear regression was used to analyse the relationship between them. With age as the predictor, $0.014 \%$ variance of work-life balance among higher education lecturers is explained $(\beta=.140$, Sig. $=.067)$.

$R Q 2$ explores the potential curvilinearity of the relationship between age and work-life balance among higher education lecturers. Regressions in which the age and its squared value are independent variables, and work-life balance among higher education lecturers is the dependent variable, have been made (Table 2).

Table 2

Testing the potential curvilinearity $R Q 2$

\begin{tabular}{rr}
\hline & $\begin{array}{c}\text { Work-life balance among } \\
\text { higher education lecturers }\end{array}$ \\
\hline $\mathrm{Age}$ & $-.282(.676)$ \\
$\mathrm{Age}^{2}$ & $.425(.529)$ \\
$\mathrm{Adj} . \mathrm{R}^{2}$ & .010 \\
$\mathrm{~F}$ & 1.890 \\
\hline
\end{tabular}

Note. Calculated by the authors. Presented are standardized coefficients $\beta$ and statistical significances (Sig.) in brackets.

In Figure 1 we present the linear and squared regression model in regard to, what happens, when independent variables of age and the squared value of the variable age increase and how it affects the dependent variable of work-life balance among higher education lecturers. Adjusted $\mathrm{R}^{2}$ shows that very small portion of variance $(1.0 \%)$ in our dependent variable is explained by our independent variables. We can neither confirm nor deny curvilinearity between age and work-life balance among higher education lecturers because of the lack of statistical significance.

Linear regression was used first, to analyse the relationship between the academic rank and work-life balance among higher education lecturers. After that we tested the potential curvilinearity of their relationship. With the academic rank as the predictor, $-0.4 \%$ variance of work-life balance among higher education lecturers is explained $(\beta=.038$, Sig. $=.618)$, which is very low and not statistically significant. 


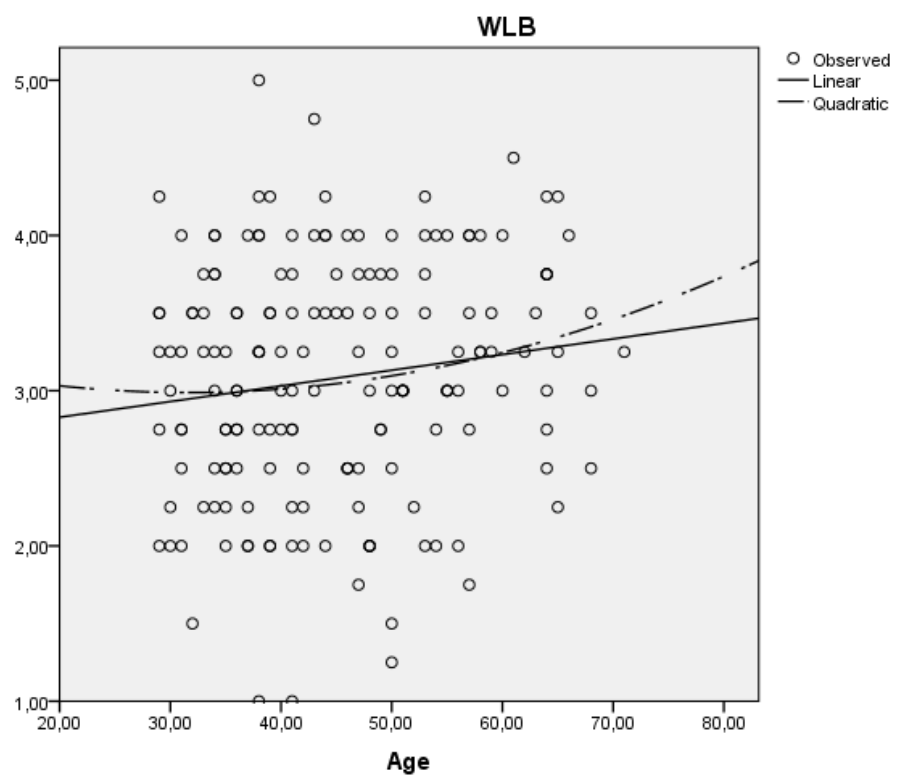

Figure 1. A graphic representation of the curvilinearity test for RQ2 Note. Calculated by the authors.

In RQ3, the potential curvilinearity of the relationship between the academic rank and work-life balance among higher education lecturers is explored. We have used the same analysis approach as before, only this time with the academic rank and its squared value as independent variables, and work-life balance among higher education lecturers as the dependent variable (Table 3 ). Adjusted $\mathrm{R}^{2}$ shows that very small portion of variance (1.0\%) in our dependent variable is explained by our independent variables. As was the case before, we can neither confirm nor deny curvilinearity between the academic rank and work-life balance among higher education lecturers, because it lacks statistical significance.

The linear and quadratic regression model in figure two present, what happens, when independent variables academic rank and the squared value of the variable academic rank increase and how it affects the dependent variable of work-life balance among higher education lecturers. With a higher academic rank the work-life balance among higher education lecturers' increases. 
8| THE EFFECT OF GENDER, AGE AND ACADEMICA RANK ON WORK-LIFE BALANCE

Table 3

Testing the potential curvilinearity $R Q 3$

\begin{tabular}{lr}
\hline & $\begin{array}{l}\text { Work-life balance among } \\
\text { higher education lecturers }\end{array}$ \\
\hline Academic rank & $-.598(.090)$
\end{tabular}

Academic rank2

$.652(.065)$

Adj. R2

.010

F

1.855

Note. Calculated by the authors. Presented are standardized coefficients $\beta$ and statistical significances (Sig.) in brackets.

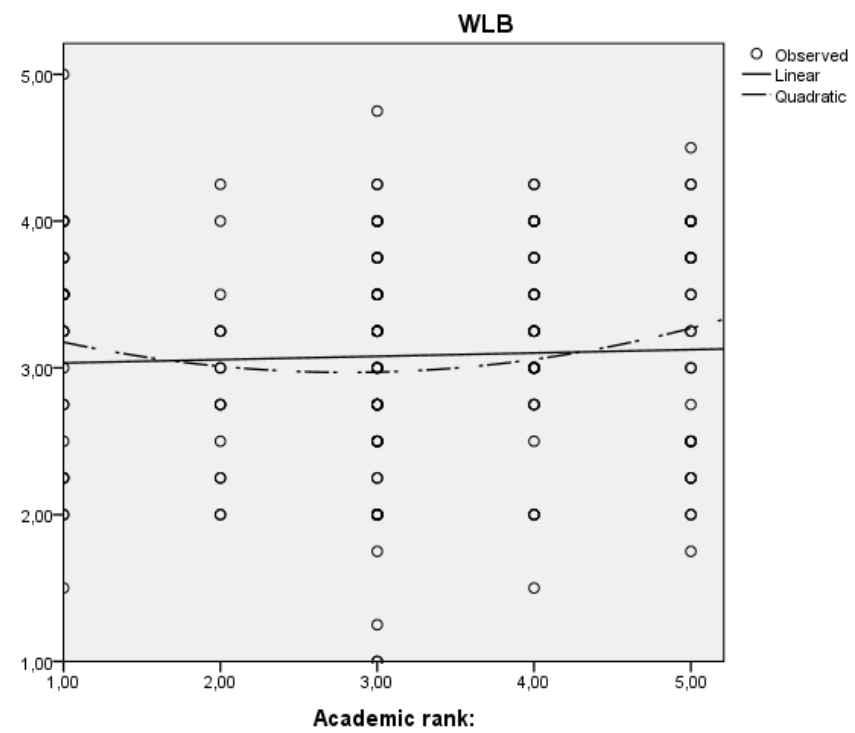

Figure 2. A graphic representation of the curvilinearity test for RQ3 Note. Calculated by the authors.

\section{CONCLUSION}

Because of the nature of their work, higher education lecturers often face difficulties in work-life balance (Erdamar and Demirel, 2014). Since researches mainly focus on impact of organizational family friendly policies and practices, we decided to research demographics' effect on work-life balance. 
Our research results show that with a higher academic rank the work-life balance among higher education lecturers increases. Oppositely, even though we expected that the relations among the demographic values and work-life balance among higher education lecturers would be positive and significant, we cannot with statistical significance claim a curvilinear relationship when it comes to the effects of age. Our results also show that there is no significant relationship between female and male.

There were some limitations of this research. The study was focused mostly on how some demographics, namely gender, age and academic rank, affect higher education lecturers' work-life balance, whereas some other demographics (e.g. number of preschool children, marital status, education,...) or other determinants were not considered, and there are also other factors involved in achieving work-life balance. For further research, we suggest investigating the effects of the determinants not included in our study.

Results of this study can be used both, for further research and practice. The theoretical contribution of this study is to the existing research of work-life balance. The practical contribution is in the presented results that the relations are also present in the case of higher education lecturers.

Successful work-life balance has many positive impacts, such as the individual's work engagement (Bedarkar and Pandita, 2014) and work commitment (Caesens and Stinglhamber, 2014) therefore it is important for organizations to help employees to balance work and family with various family-friendly policies and practice. Regardless of gender, education, family background or workplace, each employee should also have time to spend a good time on his spare time, for children, friends, family or a wider community.

\section{REFERENCES}

Bedarkar, M., \& Pandita, D. (2014). A study on the drivers of employee engagement impacting employee performance. Procedia - Social and Behavioral Sciences, 133, 106-115.

Boyar, S. L., Maertz, C. P. Jr., Mosley, D. C. Jr., \& Carr, J. C. (2008). The impact of work/family demand on work-family conflict. Journal of Managerial Psychology, 23(3), 215-235.

Brough, P., Timms, C., O'Driscoll, M. P., Kalliath, T., Oi-Ling Siu, Sit, S. \& Lo, D. (2014). Work-life balance: a longitudinal evaluation of a new measure across Australia and New Zealand workers. The International Journal of Human Resource Management, 25(19), 2724-2744. 
10 | THE EFFECT OF GENDER, AGE AND ACADEMICA RANK ON WORK-LIFE BALANCE

Caesens, G., \& Stinglhamber, F. (2014). The relationship between perceived organizational support and work engagement: The role of self-efficacy and its outcomes. Revue européenne de psychologie appliquée, 64, 259267.

Erdamar, G. \& Demirel, H. (2014) Investigation of work-family, family-work conflict of the teachers. Procedia - Social and Behavioral Sciences 116( 2014), 4919 - 4924.

Etikan, I., Abubakar Musa, S., \& Sunusi Alkassim, R. (2016). Comparison of Convenience Sampling and Purposive Sampling. American Journal of Theoretical and Applied Statistics, 5(1), 1-4.

Ferguson, M., Carlson, D., Zivnuska, S., \& Whitten, D. (2012). Support at work and home: The path to satisfaction through balance. Journal of Vocational Behavior, 80, 299-307.

Greenhaus, J. H., Ziegert, J. C., \& Allen, T. D. (2012). When family-supportive supervision matters: Relations between multiple sources of support and work-family balance. Journal of Vocational Behavior, 80, 266-275.

Guest, D. E. (2002). Perspectives on the Study of Work-life Balance. Social Science Information, 41(2), 255-279.

Kashyap, S., Joseph, S., \& Deshmukh, G. K. (2016) Employee Well - Being, Life Satisfaction and the need for Work - Life balance. Journal of Ravishankar University, Part - A, 22, 11 -23.

Lapierre, L. M., Spector, P. A., Allen, T. D., Poelmans, S., Cooper, C. L., O’Driscoll, M. P., Sanchez, J. I., Brough, P., \& Kinnunen, U. (2008). Family-supportive organization perceptions, multiple dimensions of work-family conflict, and employee satisfaction: A test of model across five samples. Journal of Vocational Behavior, 73, 92-106.

Maxwell, G. A. (2005). Checks and balances: the role of managers in work-life balance policies and practices. Journal of Retailing and Consumer Services, 12, 179-189.

McMillan, H. S., Morris, M. L., \& Atchley, E. K. (2011) Constructs of the Work/ Life Interface: A Synthesis of the Literature and Introduction of the Concept of Work/Life Harmony. Human Resource Development Review, 10(1) 6-25.

Othman, N., Yusof, S. A. M., \& Osman, W. R. S. (2009). A Conflict between Professional vs. Domestic Life? Understanding the Use of ICT in Teleworking for Balance in Work and Family Units. Computer and Information Science, 2(2), 3-15. 
Miha Marič, Jasmina Žnidaršič | 11

Parakandi, M., \& Behery, M. (2016). Sustainable human resources: Examining the status of organizational work-life balance practices in the United Arab Emirates. Renewable and Sustainable Energy Reviews, 55, 13701379.

Roeters, A. (2011). Cross-National Differences in the Association Between Parental Work Hours and Time with Children in Europe: A Multilevel Analysis. Soc Indic Res, 110, 637-658.

Skinner, N., \& Pocock, B. (2008). Work-life conflict: Is work time or work overload more important? Asia Pacific Journal of Human Resources, 46, 303-315.

Southworth, E. M. (2014). Shedding gender stigmas: Work-life balance equity in the 21st century. Business Horizons, 57, 97-106.

Stier, H., Lewin-Epstein, N., \& Braunc, M. (2012) Work-family conflict in comparative perspective: The role of social policies. Research in Social Stratification and Mobility, 30, 265-279.

Sukalova, V., Ceniga, P., \& Janotova, H. (2015). Harmonization of work and family life in company management in Slovakia. Procedia Economics and Finance, 26, $152-159$.

Suresh, S., \& Kodikal, R. (2017). SEM approach to explore Work Life Balance: A study among nurses of Multispecialty Hospitals. SJOM, Sahyadri Journal of Management, 1(1), 1-17.

Trefalt, S., Drnovsek, M., Svetina-Nabergoj, A., \& Adlesic, R. V. (2013). Work-life experiences in rapidly changing national contexts: Structural misalignment, comparisons and choice overload as explanatory mechanisms. European Management Journal, 31, 448- 463.

Turliuc, M. N., \& Buliga, D. (2014) Work-Family Conflict and Job and Family Satisfaction. The Mediating Role of Cognitions. Procedia - Social and Behavioral Sciences, 159, 105-109.

Delivered: 08.11.2018. Accepted: 25.03.2019. 